\title{
Aquatic macrophytes as biological indicators of environmental conditions of rivers in north-eastern Spain
}

\author{
M. Onaindia1*, I. Amezaga ${ }^{1}$, C. Garbisu² ${ }^{2}$ B. García-Bikuña ${ }^{3}$ \\ ${ }^{1}$ Dept. Plant Biology and Ecology, University of the Basque Country, P. O. Box 644, E-48080 Bilbao, Spain \\ 2 Neiker, Basque Institute of Agricultural Research and Development, E-48160 Derio, Spain \\ 3 Anbiotek, S.L., Lehendakari Agirre n² 29, E-48014 Bilbao, Spain
}

\begin{abstract}
The aim of this work was to evaluate the potential of aquatic macrophytes as biological indicators of the environmental conditions of rivers in north-eastern Spain. To this end, twenty five river basins were studied to assess the species composition and abundance of macrophytes, and to examine their relation with different geographic, morphometric, mineralization, and trophic status parameters. Of the twenty six macrophyte species found, five appeared to be useful as biological indicators of the environmental conditions of the rivers. L. minor was a good indicator of high mineralization (i.e., conductivity and $\mathrm{Cl}^{-}$) and high trophic state (especially, ${\mathrm{N}-\mathrm{NO}_{2}}^{-}$). C. stagnalis was a good indicator of high $\mathrm{P}-\mathrm{PO}_{4}{ }^{3-}$ concentrations. $P$. crispus, P. polygonifolius, and $R$. penicillatus seemed to be useful indicators of high $\mathrm{N}^{-\mathrm{NO}_{3}}{ }^{-}$concentration. We conclude that, in our study area, aquatic macrophytes can indeed be used as biological indicators of the environmental conditions of rivers.
\end{abstract}

Keywords : aquatic plant, geomorphology, high trophic state, mineralization, river, water quality.

\section{Introduction}

It is a well-known fact that the structure of aquatic vegetation in rivers can change as a result of both nutrient enrichment (Tusseau-Vuillemin 2001, SánchezCarrillo \& Álvarez-Cobelas 2001) and the presence of pollutants (Bernez et al. 2001). Moreover, aquatic macrophytes have been reported to improve water quality (Wilcock \& Nagels 2001, Thiébaut \& Muller 2003) and to affect algal growth (Nakai et al. 1999) as well. Likewise, the diversity of macrophyte species can have an effect on the functioning of wetland ecosystems (Engelhardt \& Ritchie 2001). Most importantly, the maintenance of this diversity is thought to enhance the numerous services that wetland ecosystems can provide to human society (Engelhardt \& Ritchie 2001, Thiébaut \& Muller 2003).

Aquatic macrophytes can obtain nutrients from the

\footnotetext{
* Corresponding author : E-mail : gvponolm@lg.ehu.es
}

sediment as well as directly from the water itself (Denny 1972, Chambers et al. 1989, Levin et al. 2001, Schulz et al. 2003, Thiébaut \& Muller 2003). Consequently, the availability of sediment nutrients may limit the growth and distribution of macrophytes (Spencer \& Ksander 2003), thus complicating interpretation of the data concerning them (Kelly \& Whitton 1998). Indeed, several studies have failed to link the distribution of macrophyte species to sediment conditions in British lowland rivers (Clarke \& Wharton 2001, Clarke 2002, Mainstone \& Parr 2002) and to separate, for instance, the effect of nutrient enrichment on macrophyte distribution from the effect of other environmental factors (such as conductivity), and the effect of $\mathrm{pH}$ from phosphate and ammonium enrichment (Dawson \& Szoszkiewicz 1999, Thiébaut \& Muller 1999). On the other hand, recent research has shown that local environmental conditions may be a less important factor than species colonisation processes in the distribution of macrophyte species (Demars \& Harper 2005).

Despite their limitations, macrophytes are undoub- 
tedly useful indicators of the environmental conditions of rivers, such as high trophic state (Kelly 1998, Thiébaut \& Muller 1999, Amoros et al. 2000, Kohler \& Schneider 2003, Schneider \& Melzer 2004). In fact, many authors have reported on macrophytes' role as valuable biological indicators of river water quality (Haslan 1987, Peñuelas \& Sabater 1987, Romero \& Onaindia 1995, Lazaridou et al. 1997, Szymanowska et al. 1999, Lehmann \& Lachavanne 1999, Haslam 2000, Klumpp et al. 2002, Demirezen \& Askoy 2004). In this respect, an increase in certain nutrients and the presence of pollutants are known to have an effect on the distribution of aquatic macrophytes (Bernez et al. 2001, Samecka-Cymerman \& Kempers 2002). In particular, macrophytes can be used as metal accumulators (Comin et al. 1997).

Certain macrophyte species and groups of species have been described as biological indicators of morphometrical characteristics and the physical features of streams (Martínez-Taberner \& Moyá 1993, Grasmück et al. 1995, Dawson et al. 2002, Ludovisi et al. 2004, Reid \& Quinn 2004). Aquatic macrophytes seem to respond in a predictable way to the trophic and physical characteristics of rivers (Haury \& Peltre 1993, Haury 1996, Spink \& Murphy 1997, Ali et al. 1999). In fact, the correlation of aquatic plants against environmental parameters indicates the environmental preferences and ranges of each plant or plant community (Dawson \& Szoszkiewick 1999). Most importantly, Harper et al. (2000) demonstrated that the development of methods to assess the ecological integrity of running waters requires the integration of both physical and chemical parameters, as well as their effects upon biological structure.

Descriptions of how river macrophytes respond to environmental factors have varied in accordance with the scale of the environmental variation observed (Jackson \& Charles 1987, Onaindia et al. 1996). Also and most importantly, it is known that the range of water trophic status and mineral content over which macrophytes are found varies significantly from one region to another, with the result that aquatic macrophytes' potential as biological indicators of the environmental conditions of rivers may differ from one place to another. In consequence, the aim of the work described in this article was to determine the links between the physical and chemical variables of rivers and the distribution of aquatic macrophytes, in an attempt to evaluate the potential of these plants as biological indicators of the environmental conditions of rivers in north-eastern Spain.

\section{Study area, materials and methods}

The study was carried out in the Basque Country in north-eastern Spain. This region is topographically divided into two waterheds by the Vasco-Cantábrica mountain range (Salvada, Gorbea, Amboto, Aitzgorri and Aralar). On the northern side of this mountain range, rivers drain into the Bay of Biscay, while on the southern side they flow via the Ebro river into the Mediterranean Sea. The substrate of the studied area is limestone. Intensive agricultural crops are widespread on the southern side of the watershed (Docampo et al. 1989). Mean annual rainfall is $1,200 \mathrm{~mm}$ and the temperature of river waters ranges from $6-8^{\circ} \mathrm{C}$ in winter to $17-20^{\circ} \mathrm{C}$ in summer (Sánz de Galdeano \& Madariaga 1992).

Thirteen main river basins and five small coastal rivers draining into the Bay of Biscay, together with seven river basins draining into the Ebro river, were studied as a representative sample of the environmental diversity within the Basque Country. Two hundred and forty six sampling stations were set up in the network of rivers.

Sampling of the vegetation was carried out over 100 $\mathrm{m}$ stretches of the rivers in summer, between June and August. Percentage of cover was recorded as a measure of the abundance of aquatic macrophytes, using a scale of 1 to $5: 1=1-10 \%, 2=11-25 \%, 3=26-50 \%$, $4=51-75 \%$ and $5=76-100 \%$ (Onaindia et al. 1996). The nomenclature in this article is in accordance with Flora Europea (Tutin et al. 1964-1980) and Flora del País Vasco (Aizpuru et al. 2000).

Geographic and morphometric parameters were also studied, together with water quality variables, as indicators of mineralization and trophic status. At each sampling station, geographic and morphometric factors, namely altitude, stream order, gradient, width of stream, mean depth, and water velocity, were measured in the field. The last three factors were used to calculate flow-rate (discharge). Water samples were taken throughout the year : winter, spring, summer and autumn. Conductivity, $\mathrm{pH}$, oxygen $\left(\mathrm{O}_{2}\right)$ concentration and water temperature were also measured in the field.

Water mineralization was determined by measuring its conductivity, hardness, alkalinity, and calcium $\left(\mathrm{Ca}^{2+}\right)$, magnesium $\left(\mathrm{Mg}^{2+}\right)$, carbonate $\left(\mathrm{CO}_{3}{ }^{2-}\right)$, sulphate $\left(\mathrm{SO}_{4}{ }^{2-}\right)$, potassium $\left(\mathrm{K}^{+}\right)$, sodium $\left(\mathrm{Na}^{+}\right)$and chloride $\left(\mathrm{Cl}^{-}\right)$concentration. Trophic status was determined according to the following parameters: $\mathrm{pH}$, dissolved $\mathrm{O}_{2}$, phosphate $\left(\mathrm{PO}_{4}{ }^{3-}\right)$, nitrite $\left(\mathrm{NO}_{2}{ }^{-}\right)$, nitrate $\left(\mathrm{NO}_{3}{ }^{-}\right)$, and ammonium $\left(\mathrm{NH}_{4}{ }^{+}\right)$concentration. Laboratory analysis for $\mathrm{Ca}^{2+}, \mathrm{Cl}^{-}, \mathrm{SO}_{4}{ }^{2-}, \mathrm{PO}_{4}{ }^{3-}, \mathrm{NO}_{2}{ }^{-}, \mathrm{NO}_{3}{ }^{-}$, 
and $\mathrm{NH}_{4}{ }^{+}$was carried out following standard methods (APHA/AWNA/VPCP 1985, Golterman 1969). Hardness was calculated according to Seddon (1972). Maps (scale 1:50.000) were used to determine altitude, slope, river order, and distance from source.

Relationships between physicochemical variables and plant cover were analysed by Spearman's rank correlation coefficient. Experiment-wise error rate was adjusted (separately for each variable studied) by the use of the Bonferroni correction. Mean values of parameters were compared with ANOVA results, since extremely stenoecious species will likely not show any correlation with an environmental parameter as they grow exclusively in certain environmental conditions. Statistical analysis was performed using Stat View (Abacus Concepts 1986) and SPSS (SPSS Inc. 1999).

\section{Results}

\section{Chemical characteristics of rivers}

Mean values of some physical and chemical parameters measured in the studied rivers are given in Table 1. In this table, it can be seen that the sites where the different aquatic macrophytes were present indeed showed a wide range of physical and chemical conditions, from moderately acidic $(\mathrm{pH}=5.1)$ to moderately basic $(\mathrm{pH}=8.8)$, and from oligotrophic $\left(\mathrm{P}^{-} \mathrm{PO}_{4}{ }^{3-}\right.$ and $\mathrm{N}-$ $\mathrm{NH}_{4}{ }^{+}$concentrations below detection limits) to meso-, eutrophic $\left(\mathrm{P}_{-} \mathrm{PO}_{4}{ }^{3-}=93.04 \mu \mathrm{g} \mathrm{l}^{-1}\right.$ and $\mathrm{N}-\mathrm{NH}_{4}{ }^{+}=25.00$ $\left.\mathrm{mg}^{-1}\right)$. In these same sites, conductivity values varied between 108 and 9,560 $\mu \mathrm{S} \mathrm{cm}^{-1}$. These high conductivity values were most likely due, in some cases, to the influence of seashore and, in others, to pollution.

In general, rivers in the study area showed high mineral contents (data not shown), especially for $\mathrm{Ca}^{2+}$ (in $\mathrm{mg} \mathrm{l}^{-1}$ : maximum value $=372.74$, minimum value $=$ 14.20 , mean value $=74.93$ ), most likely due to the limestone substratum on which they flow.

Nutrient levels in the studied waters were relatively high. Mean values of $\mathrm{N}-\mathrm{NH}_{4}{ }^{+}, \mathrm{N}-\mathrm{NO}_{2}{ }^{-}$, and $\mathrm{P}_{-} \mathrm{PO}_{4}{ }^{3-}$ at the study sites were $1.03 \pm 0.31 \mathrm{mg} \mathrm{l}^{-1}, 28.27 \pm 6.05 \mathrm{\mu g} \mathrm{l}^{-1}$, and $5.19 \pm 1.09 \mathrm{\mu g}^{-1}$, respectively.

\section{Aquatic plant species}

Twenty six different species of aquatic macrophytes were recorded at 124 of the sampling stations. Out of these twenty six species, only those present in more than $2 \%$ of the macrophyte-recorded stations (i.e., stations where macrophytes were found) were considered in this study, viz. Apium nodiflorum, Callitriche stagnalis, Groenlandia densa, Lemna minor, Myriophyllum spicatum, Nasturtium officinale, Potamogeton crispus, Potamogeton polygonifolius, Ranunculus penicillatus, Veronica beccabunga, and Zannichellia palustris (i.e., a total of 11 species).

The most abundant species, present in a broad range of environmental conditions, was A. nodiflorum (present in $33 \%$ of the macrophyte-recorded stations). This species was not included in the ANOVA analysis as it

Table 1. Mean pooled values (with min - max in brackets) of the relevant physicochemical parameters for all macrophyte-recorded stations and for the stations where the most frequent macrophytes were found.

\begin{tabular}{|c|c|c|c|c|c|c|c|c|c|}
\hline & $\begin{array}{l}\text { Conductivity } \\
\left(\mu \mathrm{S} \mathrm{cm}^{-1}\right)\end{array}$ & $\begin{array}{c}\text { Temperature } \\
\left({ }^{\circ} \mathrm{C}\right)\end{array}$ & $\begin{array}{c}\mathrm{Cl}^{-} \\
\mathrm{mg} \mathrm{I}^{-1}\end{array}$ & 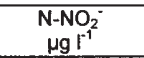 & $\begin{array}{l}\mathrm{N}-\mathrm{NO}_{3}{ }^{-} \\
\mu \mathrm{g} \mathrm{I}^{-1}\end{array}$ & $\begin{array}{l}\mathrm{P}-\mathrm{PO}_{4}{ }^{3-} \\
\mathrm{\mu g} \mathrm{I}^{-1}\end{array}$ & $\begin{array}{l}\mathrm{N}-\mathrm{NH}_{4}^{+} \\
\mathrm{\mu g} \mathrm{^{-1 }}\end{array}$ & $\begin{array}{c}\text { Dissolved } \mathrm{O}_{2} \\
\mathrm{mg} \mathrm{I}^{-1}\end{array}$ & $\overline{\mathrm{pH}}$ \\
\hline $\begin{array}{l}\text { Macrophyte- } \\
\text { recorded stations }\end{array}$ & $\begin{array}{c}652 \\
(108-9560)\end{array}$ & $\begin{array}{c}16.14 \\
(8.50-22)\end{array}$ & $\begin{array}{c}60.40 \\
(6.74-1910)\end{array}$ & $\begin{array}{c}28.27 \\
(0.03-631)\end{array}$ & $\begin{array}{c}3.77 \\
(0-28.61)\end{array}$ & $\begin{array}{c}5.19 \\
(0-93.04)\end{array}$ & $\begin{array}{l}1.03 \\
(0-25)\end{array}$ & $\begin{array}{c}8.11 \\
(2.15-13.60)\end{array}$ & $\begin{array}{c}7.54 \\
(5.10-8.80)\end{array}$ \\
\hline A.nudiforum & $\begin{array}{c}871 \\
(217-9560)\end{array}$ & $\begin{array}{c}16.55 \\
(9.50-21)\end{array}$ & $\begin{array}{c}101.93 \\
(9.70-1910)\end{array}$ & $\begin{array}{c}48.57 \\
(0.35-631)\end{array}$ & $\begin{array}{c}2.23 \\
(0-22)\end{array}$ & $\begin{array}{c}10.61 \\
(0-93.04)\end{array}$ & $\begin{array}{c}1.84 \\
(0-25)\end{array}$ & $\begin{array}{c}7.17 \\
(2.15-13.60)\end{array}$ & $\begin{array}{c}7.42 \\
(6.20-8.60)\end{array}$ \\
\hline C. stagnalis & $\begin{array}{c}513 \\
(353-651)\end{array}$ & $\begin{array}{c}17.35 \\
(15.50-20)\end{array}$ & $\begin{array}{c}36.12 \\
(22.36-71)\end{array}$ & $\begin{array}{c}30.90 \\
(3-80.64)\end{array}$ & $\begin{array}{c}1.50 \\
(0.15-5.19)\end{array}$ & $\begin{array}{c}9.54 \\
(0.63-22.94)\end{array}$ & $\begin{array}{l}0.66 \\
(0-4)\end{array}$ & $\begin{array}{c}8.45 \\
(2.54-13.60)\end{array}$ & $\begin{array}{c}7.45 \\
(6.90-8.60)\end{array}$ \\
\hline G. densa & $\begin{array}{c}583 \\
(314-1524)\end{array}$ & $\begin{array}{c}16.69 \\
(12.00-22)\end{array}$ & $\begin{array}{c}36.17 \\
(10.93-87.19)\end{array}$ & $\begin{array}{c}14.02 \\
(0.23-45.01)\end{array}$ & $\begin{array}{c}4.48 \\
(0-13.80)\end{array}$ & $\begin{array}{c}1.62 \\
(0-6.48)\end{array}$ & $\begin{array}{c}2.11 \\
(0.01-10)\end{array}$ & $\begin{array}{c}8.96 \\
(6.83-11.10)\end{array}$ & $\begin{array}{c}7.53 \\
(6.80-8.30)\end{array}$ \\
\hline L. minor & $\begin{array}{c}1061 \\
(507-2880)\end{array}$ & $\begin{array}{c}17.14 \\
(11.30-21)\end{array}$ & $\begin{array}{c}125.17 \\
(22.72-420.67)\end{array}$ & $\begin{array}{c}70.13 \\
(0.87-187.09)\end{array}$ & $\begin{array}{c}3.08 \\
(0.01-20.15)\end{array}$ & $\begin{array}{c}5.16 \\
(0.29-11.98)\end{array}$ & $\begin{array}{c}0.27 \\
(0.47-0.50)\end{array}$ & $\begin{array}{c}7.8 \\
(3.95-10.45)\end{array}$ & $\begin{array}{c}7.03 \\
(5.10-8.60)\end{array}$ \\
\hline M. spicatum & $\begin{array}{c}619 \\
(353-745)\end{array}$ & $\begin{array}{c}15.07 \\
(10.00-20)\end{array}$ & $\begin{array}{c}47.02 \\
(26.27-79.75)\end{array}$ & $\begin{array}{c}21.79 \\
(0.10-81.91)\end{array}$ & $\begin{array}{c}6.77 \\
(0.57-20.15)\end{array}$ & $\begin{array}{c}1.93 \\
(0.18-4.23)\end{array}$ & $\begin{array}{c}0.11 \\
(0.47-0.25)\end{array}$ & $\begin{array}{c}8.39 \\
(5.3-10)\end{array}$ & $\begin{array}{c}7.27 \\
(5.10-8.10)\end{array}$ \\
\hline N. officinale & $\begin{array}{c}421 \\
(217-756)\end{array}$ & $\begin{array}{c}14.99 \\
(8.50-22)\end{array}$ & $\begin{array}{c}21.38 \\
(8.58-71)\end{array}$ & $\begin{array}{c}4.04 \\
(0.70-15.26)\end{array}$ & $\begin{array}{c}1.96 \\
(0-7.20)\end{array}$ & $\begin{array}{c}0.48 \\
(0-2.48)\end{array}$ & $\begin{array}{c}0.07 \\
(0-0.30)\end{array}$ & $\begin{array}{c}9.26 \\
(7.31-11.46)\end{array}$ & $\begin{array}{c}7.89 \\
(7.10-8.80)\end{array}$ \\
\hline P. crispus & $\begin{array}{c}608 \\
(228-1008)\end{array}$ & $\begin{array}{c}13.97 \\
(11.50-16.30)\end{array}$ & $\begin{array}{c}38.46 \\
(10.98-68.85)\end{array}$ & $\begin{array}{c}27.16 \\
(0.22-124.71)\end{array}$ & $\begin{array}{c}12.93 \\
(0.68-22.54)\end{array}$ & $\begin{array}{c}2.40 \\
(0-11.14)\end{array}$ & $\begin{array}{c}0.21 \\
(0.03-0.54)\end{array}$ & $\begin{array}{c}7.44 \\
(5.12-10.40)\end{array}$ & $\begin{array}{c}7.68 \\
(7.30-8.20)\end{array}$ \\
\hline P. polygonifolius & $\begin{array}{c}581 \\
(314-777)\end{array}$ & $\begin{array}{c}13.16 \\
(11.60-14.10)\end{array}$ & $\begin{array}{c}50.69 \\
(19.78-84.78)\end{array}$ & $\begin{array}{c}0.25 \\
(0.98-0.38)\end{array}$ & $\begin{array}{c}9.71 \\
(7.2-12.03)\end{array}$ & $\begin{array}{c}0.37 \\
(0-0.86)\end{array}$ & $\begin{array}{c}0.03 \\
(0.01-0.05)\end{array}$ & $\begin{array}{c}6.46 \\
(5.2-8.70)\end{array}$ & $\begin{array}{c}7.4 \\
(7.10-7.80)\end{array}$ \\
\hline R. peniccillatus & $\begin{array}{c}410 \\
(108-837)\end{array}$ & $\begin{array}{c}13.09 \\
(10.20-16.40)\end{array}$ & $\begin{array}{c}26.54 \\
(10.93-84.72)\end{array}$ & $\begin{array}{c}0.29 \\
(0.03-0.87)\end{array}$ & $\begin{array}{c}11.05 \\
(6.25-28.61)\end{array}$ & $\begin{array}{c}0.23 \\
(0-1.63)\end{array}$ & $\begin{array}{c}0.02 \\
(0-0.09)\end{array}$ & $\begin{array}{c}8.69 \\
(5.20-11.60)\end{array}$ & $\begin{array}{c}7.86 \\
(6.60-8.50)\end{array}$ \\
\hline V. beccabunga & $\begin{array}{c}455 \\
(201-1502)\end{array}$ & $\begin{array}{c}16.99 \\
(8.60-21)\end{array}$ & $\begin{array}{c}31.82 \\
(6.74-262.7)\end{array}$ & $\begin{array}{c}7.47 \\
(0.19-34.76)\end{array}$ & $\begin{array}{c}1.54 \\
(0-7.20)\end{array}$ & $\begin{array}{c}4.07 \\
(0-29.80)\end{array}$ & $\begin{array}{c}0.78 \\
(0-10)\end{array}$ & $\begin{array}{c}8.92 \\
(2.15-13.11)\end{array}$ & $\begin{array}{c}7.71 \\
(6.70-8.60)\end{array}$ \\
\hline Z. palustris & $\begin{array}{c}524 \\
(401-723) \\
\end{array}$ & $\begin{array}{c}19.25 \\
(19.00-20)\end{array}$ & $\begin{array}{c}29.02 \\
(12.78-48.99)\end{array}$ & $\begin{array}{c}49.17 \\
(4.68-81.91) \\
\end{array}$ & $\begin{array}{c}1.14 \\
(0-2.70)\end{array}$ & $\begin{array}{c}2.76 \\
(0.39-5.82)\end{array}$ & $\begin{array}{c}2.67 \\
(0.10-10)\end{array}$ & $\begin{array}{c}8.64 \\
(6.94-10.51)\end{array}$ & $\begin{array}{c}7.85 \\
(7.50-8.30)\end{array}$ \\
\hline
\end{tabular}


introduced high variability. By contrast, the least frequent species was $P$. polygonifolius, present in just $2 \%$ of the macrophyte-recorded stations.

\section{Geographic and morphometric parameters}

Plant species distribution was significantly affected only by water temperature $\left(\mathrm{F}_{9,70}=2.58, \mathrm{p}<0.02\right)$ (Fig. $1 \mathrm{a})$. In this respect, $Z$. palustris and $R$. penicillatus were found at the highest and lowest values of mean water temperature, respectively (Fig. 1a).

\section{Mineralization parameters}

Regarding plant distribution and mineralization parameters, significant differences were found only for conductivity $\left(\mathrm{F}_{9,71}=2.25, \mathrm{p}=0.028\right)(\mathrm{Fig} .1 \mathrm{~b})$ and $\mathrm{Cl}^{-}$ concentration $\left(\mathrm{F}_{9,71}=2.09, \mathrm{p}=0.041\right)$ (Fig. 1c). L. minor was found at the highest conductivity $\left(1061.00 \pm 329.41 \mu \mathrm{S} \mathrm{cm}^{-1}\right)$ and $\mathrm{Cl}^{-}$concentration values $\left(125.17 \pm 58.57 \mathrm{mg} \mathrm{l}^{-1}\right)$, with no significant differences being observed in the distribution of the other macrophyte species (Fig. 1a,b). Mean conductivity and $\mathrm{Cl}^{-}$concentration values for $A$. nodiflorum were $871.12 \pm 237.19 \mu \mathrm{S} \mathrm{cm}^{-1}$ and $101.93 \pm 48.39 \mathrm{mg} \mathrm{l}^{-1}$, respectively.

\section{Trophic level}

The distribution of macrophyte species was significantly affected by $\mathrm{N}^{-\mathrm{NO}_{2}}{ }^{-}\left(\mathrm{F}_{9,72}=4.94, \mathrm{p}<0.0001\right)$, $\mathrm{N}-\mathrm{NO}_{3}{ }^{-}\left(\mathrm{F}_{9,72}=5.93, \mathrm{p}<0.0001\right)$, and $\mathrm{P}-\mathrm{PO}_{4}{ }^{3-}\left(\mathrm{F}_{9,68}=\right.$ 2.24, $\mathrm{p}=0.03$ ) concentration (Fig. 2). L. minor, Z. palustris, and $C$. stagnalis were found at the highest $\mathrm{N}$ $\mathrm{NO}_{2}{ }^{-}$concentrations $(70.13 \pm 22.14,49.17 \pm 16.63$, and $30.90 \pm 15.52 \mu \mathrm{g} \mathrm{l}^{-1}$, respectively), while $P$. polygonifolius, $R$. penicillatus, $N$. officinale, and $V$. beccabunga were observed at the lowest concentrations of this same anion $(0.25 \pm 0.08,0.29 \pm 0.08,4.04 \pm 1.44$, and $7.47 \pm 2.08 \mu \mathrm{g} \mathrm{l}^{-1}$, respectively) (Fig. 2a). A. nodiflorum also appeared at high levels of N-NO2- $(48.57 \pm 16.58$ $\mu \mathrm{g} \mathrm{1-1).} \mathrm{Finally,} \mathrm{A.} \mathrm{nodiflorum} \mathrm{and} \mathrm{L.} \mathrm{minor} \mathrm{were} \mathrm{po-}$ sitively correlated with $\mathrm{N}-\mathrm{NO}_{2}{ }^{-}$concentration $(\mathrm{r}=$ $0.54, \mathrm{p}=0.001$ and $\mathrm{r}=0.54, \mathrm{p}=0.0003$, respectively).

On the other hand, $P$. crispus, $R$. penicillatus, and $P$. polygonifolius were found at the highest $\mathrm{N}-\mathrm{NO}_{3}$ concentrations $(12.93 \pm 3.99,11.04 \pm 2.13$, and $9.71 \pm 1.39 \mu \mathrm{g} \mathrm{l}^{-1}$, respectively), while $Z$. palustris, $C$. stagnalis, and $V$. beccabunga were found at the lowest concentrations of this same anion $(1.14 \pm 0.58$, $1.50 \pm 0.76$, and $1.54 \pm 0.62 \mu \mathrm{g} \mathrm{l}^{-1}$, respectively) (Fig. $2 b)$. No correlation was found between the distribution of macrophyte species and river $\mathrm{N}^{-\mathrm{NO}_{3}}{ }^{-}$concentration.

Regarding $\mathrm{P}_{-} \mathrm{PO}_{4}{ }^{3-}$ concentration and macrophyte species distribution (Fig. 2c), C. stagnalis and L. minor a)

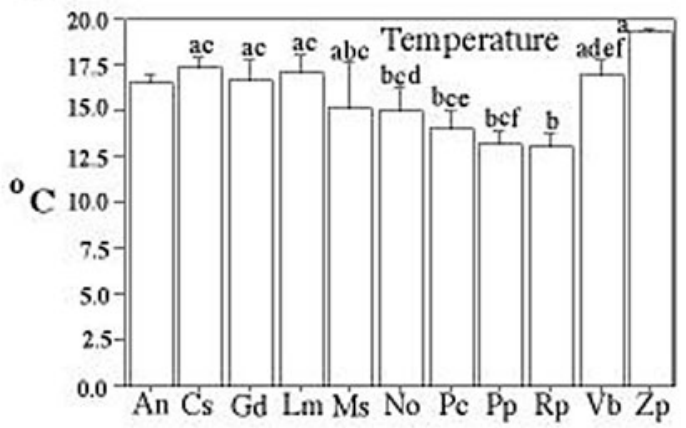

b)

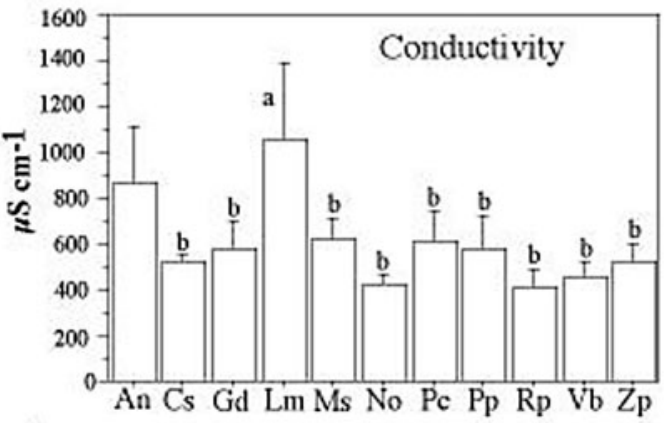

c)

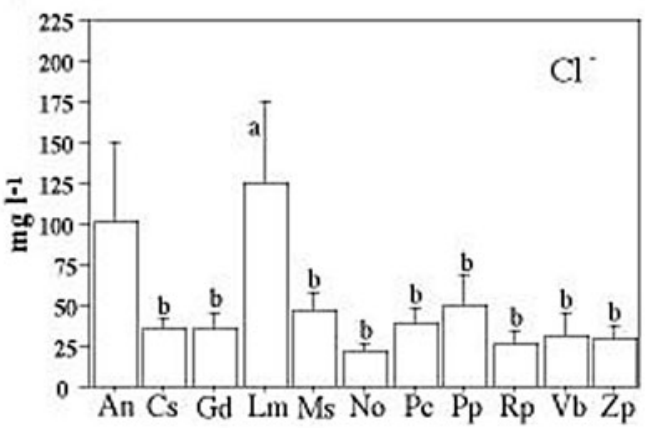

Fig. 1. Macrophyte species distribution (mean $\pm \mathrm{SE}$ ) in relation to temperature (a), conductivity (b) and chloride concentration (c). Within graphs, means with the same lower case letter are not significant at $\mathrm{p}<0.05$. Apium nudiflorum was not included in the analysis as explained in the text. An=Apium nodiflorum, $\mathrm{Cs}=$ Callitriche stagnalis, $\mathrm{Gd}=$ Groenlandia densa, $\mathrm{Lm}=$ Lemna minor, $\mathrm{Ms}=$ Myriophyllum spicatum, $\mathrm{No}=$ Nasturtium officinale, $\mathrm{Pc}=$ Potamogeton crispus, $\mathrm{Pp}=$ Potamogeton polygonifolius, $\mathrm{Ra}=$ Ranunculus penicillatus, $\mathrm{Ve}=$ Veronica beccabunga, and $\mathrm{Za}=$ Zannichellia palustris.

were found at the highest $\mathrm{P}-\mathrm{PO}_{4}{ }^{3-}$ concentration values $\left(9.54 \pm 4.25\right.$ and $5.16 \pm 1.77 \mu \mathrm{g} \mathrm{l}^{-1}$, respectively). $A$. nodiflorum also appeared at high $\mathrm{P}-\mathrm{PO}_{4}{ }^{3-}$ values (i.e., $\left.10.60 \pm 3.10 \mu \mathrm{g}^{-1}\right)$. Finally, $R$. penicillatus, $P$. polygonifolius, and $N$. officinale were found at the lowest P- 
a)

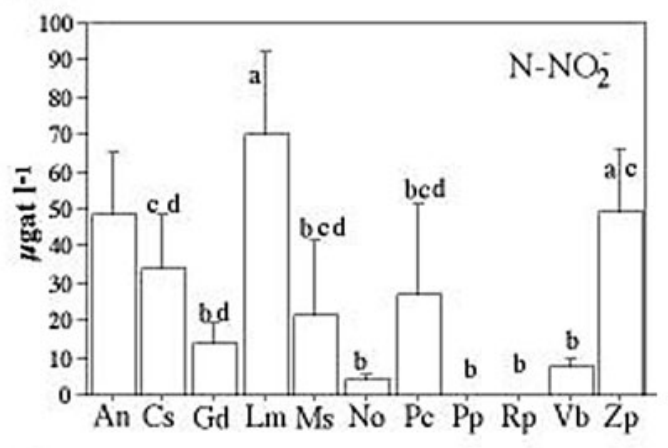

b)

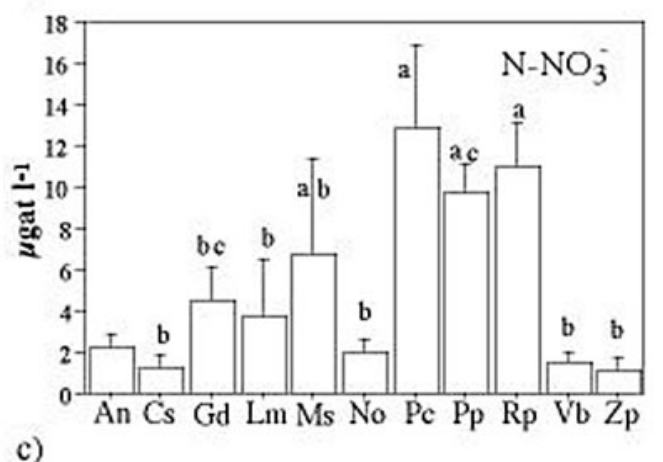

c)

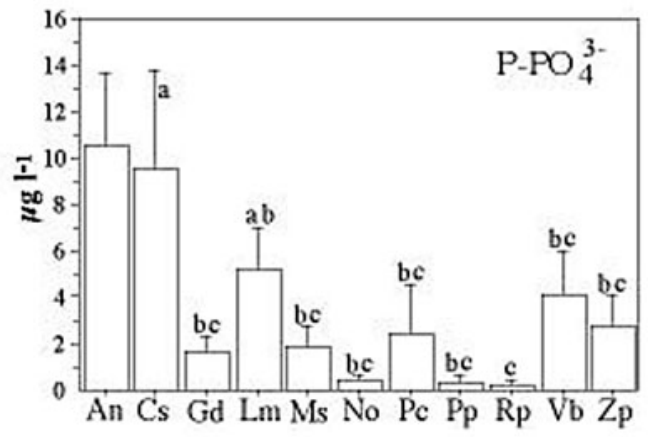

Fig. 2. Macrophyte species distribution (mean $\pm \mathrm{SE}$ ) in relation to nitrite (a), nitrate (b), and phosphate (c) concentration. Within graphs, means with the same lower case letter are not significant at $\mathrm{p}<0.05$. Apium nudiflorum was not included in the analysis as explained in the text. An= Apium nodiflorum, $\mathrm{Cs}=$ Callitriche stagnalis, $\mathrm{Gd}=$ Groenlandia densa, $\mathrm{Lm}=$ Lemna minor, $\mathrm{Ms}=\mathrm{My}$ riophyllum spicatum, $\mathrm{No}=$ Nasturtium officinale, $\mathrm{Pc}=$ Potamogeton crispus, $\mathrm{Pp}=$ Potamogeton polygonifolius, $\mathrm{Ra}=$ Ranunculus penicillatus, $\mathrm{Ve}=$ Veronica beccabunga, and $\mathrm{Za}=$ Zannichellia palustris.

$\mathrm{PO}_{4}{ }^{3-}$ concentrations $(0.23 \pm 0.16,0.37 \pm 0.25$, and $0.48 \pm 0.19 \mu \mathrm{g} \mathrm{l}^{-1}$, respectively). Again, no correlation was found between macrophyte species distribution and river $\mathrm{P}-\mathrm{PO}_{4}{ }^{3-}$ concentration.
In relation to $\mathrm{N}-\mathrm{NH}_{4}{ }^{+}$and macrophyte species distribution (Table 1), although no significant $(\mathrm{p}>0.05)$ differences were found, $A$. nodiflorum was indeed correlated with $\mathrm{N}^{-\mathrm{NH}_{4}}{ }^{+}$values $(\mathrm{r}=0.49, \mathrm{p}<0.0001)$. $Z$. $p a$ lustris and $R$. penicillatus were found at the highest $\left(2.67 \pm 1.44 \mathrm{mg} \mathrm{l}^{-1}\right)$ and lowest $\left(0.02 \pm 0.00 \mathrm{mg} \mathrm{l}^{-1}\right) \mathrm{N}$ $\mathrm{NH}_{4}{ }^{+}$concentrations, respectively.

Finally, dissolved $\mathrm{O}_{2}$ and $\mathrm{pH}$ did not show any correlation with the studied species, except for $A$. nodiflorum that was negatively correlated with $\mathrm{pH}(\mathrm{r}=-0.34$, $\mathrm{p}=0.0002)$ and showed a mean distribution value of $7.42 \pm 0.09$ (Table 1).

\section{Discussion}

Distribution of macrophyte species in the studied rivers was certainly discontinuous. Although twenty six different species of aquatic macrophytes were recorded at 124 sites, only eleven of those were present in more than $2 \%$ of the macrophyte-recorded stations (i.e., where macrophytes were found). Most importantly, only A. nodiflorum and L. minor showed correlations with the measured variables (i.e., A. nodiflorum was positively correlated with $\mathrm{N}-\mathrm{NO}_{2}{ }^{-}$and $\mathrm{N}-\mathrm{NH}_{4}{ }^{+}$ concentration and negatively correlated with $\mathrm{pH} ; L$. minor, in turn, was positively correlated with $\mathrm{N}_{-} \mathrm{NO}_{2}{ }^{-}$ concentration). Thus, in our study area, it might be concluded that the potential of aquatic macrophytes as biological indicators of the environmental conditions of rivers was somewhat restricted by the discontinuity of their distribution. This discontinuity in macrophyte distribution might be due to the specific dispersal and regeneration abilities of the macrophyte species present, as indicated by Demars \& Harper (2005).

In any case, regarding their effect on macrophyte distribution, physicochemical parameters clearly dominated over geographic and morphometric variables, probably due to the geological homogeneity of the substrate and/or the relatively high values of nutrient content and mineralization found in these waters, which would mask other effects. In this respect, dominance of geochemical parameters over chemical ones has been previously related to substrate (Grasmück et al. 1995) and morphological heterogeneity (Haury 1996) in other European rivers.

In this study, $A$. nodiflorum was the most abundant species, being distributed in all the studied rivers and within a broad range of environmental conditions. Similar results were described by Demars \& Harper (1998) in British rivers. Besides, as abovementioned, A. nodiflorum showed a positive correlation with N- 
$\mathrm{NO}_{2}{ }^{-}$and $\mathrm{N}-\mathrm{NH}_{4}{ }^{+}$, as well as a negative one with $\mathrm{pH}$. This species has the ability to oxygenate its substrate (Chorianopoulou et al. 2001) and has been reported to be a good competitor in eutrophic waters (Szakowski $\&$ Kolsowski 2001). Its abundance at the study area might be due to its good adaptation to the high values of nutrient content and mineralization found in these river waters. Thus, in our study area, A. nodiflorum, despite having been reported as a valuable indicator of high mineral content in other areas of Europe (Martínez-Taberner \& Moyá 1993), cannot be considered a useful biological indicator of the environmental conditions of rivers. After all, biological indicators must, by definition, appear only within a narrow range of a certain parameter.

Some mineralization parameters, namely, conductivity and $\mathrm{Cl}^{-}$concentration, differentiated $L$. minor distribution from that of the other macrophytes here studied, and can thus be considered a useful indicator of those two parameters. L. minor has also been reported to be a good indicator of mesotrophic waters (Dawson et al. 1999). Z. palustris has previously been reported as a good indicator of high conductivity and eutrophic sites in British rivers (Whitton et al. 1998) but in this study the distribution of this macrophyte species did not show correlation with any of the mineralization parameters here determined.

In our study area, water nutrient enrichment was the most significant factor for the differentiation of macrophyte species distribution, as already reported for other European rivers (Thiébaut \& Muller 1999, Harper et al. 2000, Lafont 2001, Thiebaut et al. 2002, Gomarasca et al. 2004). In this work, most importantly, the distribution of aquatic macrophytes depended on the specific nutrient under study. In fact, $C$. stagnalis was distributed in sites showing high $\mathrm{P}_{-} \mathrm{PO}_{4}{ }^{3-}$ concentrations, moderate levels of $\mathrm{N}^{-} \mathrm{NO}_{2}^{-}$, and low values of $\mathrm{N}_{-} \mathrm{NO}_{3}{ }^{-}$ concentration. This species has previously been found in base-rich or acidic and impoverished rivers (Palmer et al. 1992, Rodwell et al. 1995). Other authors have found it mainly in eutrophic waters (Palmer et al. 1992, Swedish EPA 2002, Thiebaut et al. 2002) and positively affected by the presence of $\mathrm{SO}_{4}{ }^{2-}$ (Gomarasca et al. 2004).

Here $L$. minor was mainly located at sites with high concentrations of $\mathrm{N}^{-} \mathrm{NO}_{2}^{-}$, as described for Italian rivers (Gomarasca et al. 2004), and moderate levels of $\mathrm{P}_{-} \mathrm{PO}_{4}{ }^{3-}$. This species has been reported as a useful indicator of a moderate degree of high trophic state (Grime et al. 1988, Palmer et al. 1992, Papastergiadou \& Babalonas 1993, Rodwell et al. 1995, Thiebaut et al. 2002, Swedish EPA 2002).
In the study sites, $P$. crispus and P. polygonifolius appeared in stations having high $\mathrm{N}_{-} \mathrm{NO}_{3}^{-}$concentrations and low levels of $\mathrm{P}_{-} \mathrm{PO}_{4}{ }^{3-}$. P. crispus has previously been linked to meso-, eutrophic sites in British rivers (Palmer et al. 1992, Rodwell et al. 1995, Dawson et al. 1999, James et al. 2002, Swedish EPA 2002). On the contrary, in French rivers, $P$. polygonifolius has been found to be an indicator of oligotrophic waters (Thiébaut \& Muller 1999, Thiébaut et al. 2002, Swedish EPA 2002). Other species of this genus, such as $P$. perfoliatus and $P$. pectinatus, have been associated to high trophic state in rivers of France, Great Britain, Poland and Germany (Grasmük et al. 1995, Rodwell et al. 1995, Dawson et al. 1999, Dawson \& Szoszkiewicz 1999, Clarke \& Wharton 2001, Szoszkiewicz et al. 2002, Shneider \& Melzer 2004, Gomarasca et al. 2004).

$N$. officinale, a species previously described for other Basque rivers as a good indicator of low mineralization (Onaindia et al. 1996), has also been found in the study area under low values of nutrient content and mineralization, but the statistical analyses have not shown its potentiality.

$R$. pennicillatus was mainly found at low $\mathrm{P}-\mathrm{PO}_{4}{ }^{3-}$

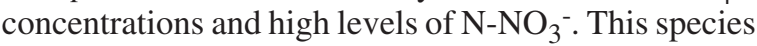
has been described in British rivers as typical of mesotrophic environments (Rodwell et al. 1995, Demars \& Harper 1998).

In conclusion, in our study area, L. minor, C. stagnalis, $P$. crispus, $P$. polygonifolius, and $R$. pennicillatus can be used as biological indicators of nutrient enrichment. L. minor is a good indicator of high mineralization (i.e., conductivity and $\mathrm{Cl}^{-}$) and high trophic state (especially, $\mathrm{N}-\mathrm{NO}_{2}^{-}$). C. stagnalis appears to be a good indicator of high $\mathrm{P}_{-} \mathrm{PO}_{4}{ }^{3-}$ concentrations. P. crispus, $P$. polygonifolius, and $R$. penicillatus can be considered useful indicators of high $\mathrm{N}_{-} \mathrm{NO}_{3}{ }^{-}$concentration.

Finally, it must be emphasized that the morphometric parameters, the range of trophic state conditions, the mineral contents, etc. over which the macrophytes here studied were found, differ from those of other regional and/or European rivers. Consequently, the results here obtained regarding the potentiality of different aquatic macrophytes as biological indicators of the environmental conditions of rivers should not be assumed to be appropriate for extrapolation to other areas.

\section{Acknowledgements}

The authors sincerely thank the University of the Basque Country for grant 9/UPV00118.310-14549/2002, CICYT for AGL 20000196-P4-03 and UNESCO 03/09. 


\section{References}

Abacus Concepts 1986. - Stat View 512+. The Solution for Data Analysis and Presentation Graphics. Brain Power Inc., Calabasas, $180 \mathrm{p}$.

Aizpuru I., Aseginolaza C., Uribe-Echebarría P., Urrutia P. \& Zorrakin I. 2000. - Claves Ilustradas de la Flora del País Vasco y Territorios Limítrofes. Servicio de Publicaciones del Gobierno Vasco, Vitoria-Gasteiz, 831p.

Ali M.M., Murphy K.J. \& Abernethy V.J. 1999. - Macrophyte functional variables versus species assemblages as predictors of trophic status in flowing waters. Hydrobiologia, 415, 131-138.

Amoros C., Bornette G. \& Henry C.P. 2000. - A vegetation based method for ecological diagnosis of riverine wetlands. Environ. Manage., 25, 211-227.

APHA, AWWA, VPCP 1985. - Standard Methods for the Examination of Water and Wastewater. XIV Ed., Washington, 1193 p.

Bernez I., Daniel, H. \& Haury J. 2001. - Effects of perturbations on the aquatic vegetation of regulated river. Bull. Fr. Pêche Pisc., 357-60, 169-189.

Chamber P.A., Prepas E.E., Bothwell M.L. \& Hamilton H.R. 1989. Roots versus shoots in nutrient uptake by aquatic macrophytes in flowing waters. Can. J. Fish.Aquat. Sci., 46, 435-439.

Chorianopoulou S.N., Bouranis D.L. \& Drossopoulos J.B. 2001. Oxygen transport by Apium nodiflorum. J. Plant Physiol., 158, 905-913.

Clarke S.J. 2002. - Vegetation growth in rivers: influences upon sediment and nutrient dynamics. Prog. Phys. Geog., 26, 159-172.

Clarke S.J. \& Wharton G. 2001. - Sediment nutrient characteristics and aquatic macrophytes in lowland English rivers. Sci. Total Environ., 266, 103-112.

Comin F.A., Romero J.A., Astorga V. \& García C. 1997. - Nitrogen removal and cycling in restored wetlands used as filters of nutrients for agricultural runoff. Water Sci. Technol., 35, 255-261.

Dawson F.H., Hornby D.D. \& Hilton J. 2002. - A method for the automated extraction of environmental variables to help classification of rivers in Britain. Aquat. Contam. Mar. Freshwat. Ecosyst. 12, 391-403.

Dawson F.H., Newman J.R., Gravelle M.J., Rouen K.J. \& Henville P. 1999. Assessment of the Trophic Status of Rivers Using Macrophytes : Evaluation of the Mean Trophic Rank. R \& D Technical Report E39, Environment Agency of England and Whales, Bristol, $190 \mathrm{p}$.

Dawson H.F. \& Szoszkiewicz K. 1999. - Relationships of some ecological factors with the associations of vegetation in British rivers. Hydrobiologia, 415, 117-122.

Demars B.O.L. \& Harper D.M. 1998. - The aquatic macrophytes of an English lowland river system. Assessing response to nutrient enrichment. Hydrobiologia, 384, 75-88.

Demars B.O.L. \& Harper D.M. 2005. - Distribution of aquatic vascular pants in lowland rivers : separating the effects of local environmental conditions, longitudinal connectivity and river basin isolation. Freshwat. Biol., 50, 418-437.

Demirezen D. \& Aksoy A. 2004. - Accumulation of heavy metals in Typha angustifolia (L.) and Potamogeton pectinatus (L.) living in sulta Marsh (Kayseri, Turkey). Chemosphere, 56, 685-696.

Denny P. 1972. - Sites of nutrient absorption in aquatic macrophytes. J. Ecol., 60, 819-829.

Docampo L., de Bikuña B.G., Rico E. \& Rallo A. 1989. - Morfometría de las cuencas de la red hidrográfica de Bizkaia. Limnetica, 5, 51-67.

Engelhardt K.A.M. \& Ritchie M.E. 2001. - Effects of macrophyte species richness on wetland ecosystems and services. Nature, 411, 687-689.

Golterman H.L. 1969. - Methods for Chemical Analysis of Freshwa- ters. IBP Handbook 8. Blackwell Scientific Publications, Oxford, $127 \mathrm{p}$.

Gomarasca S., Ferrario M., Galbiati D., Ficetola F. \& Cotta Ramusino M. 2004. - Macrophite acquatiche quali possibili indicatori di qualità ecologica del sistema irriguo minore. Convegno Internatizionale Il sistema rurale Una sfida per la progettazione tra salvaguardia, sostenibilità e governo delle trasformazioni. Milano 13 14 ottobre 2004.

Grasmück N., Haury J., Léglize L. \& Muller S. 1995. - Assessment of bio-indicator capacity of aquatic macrophytes using multivariate analysis. Hydrobiologia, 300/301, 115-122.

Grime J.P., Hodgson J.G. \& Hunt R. 1988. - Comparative plant ecology. Unwin Hyman, London 742 pp.

Harper D.M., Kemp J.L., Vogel B. \& Newson M.D. 2000. - Towards the assessment of "ecological integrity" in running waters of the United Kingdom. Hydrobiologia, 422, 133-142.

Haslam S. M. 1987. - River Plants of Western Europe. The Macrophytic Vegetation of Watercourses of the European Economic Community. Cambridge University Press, Cambridge, 512 p.

Haslam S.M. 2000. - The evaluation of river pollution using vegetation in the Maltese islands. Freshwat. Environ. Bull., 9, 347-351.

Haury J. 1996. - Assessing functional typology involving water quality, physical features and macrophytes in a Normandy river. $\mathrm{Hy}$ drobiologia, 340, 43-49.

Haury J. \& Peltre M.C. 1993. - Intérêts et limites des "indices macrophytes" pour la mésologie et la physico-chimie des cours d'eau : exemples armoricains, picards et lorrains. Ann. Limnol., 29, 239-253.

Jackson S.T.\& Charles D.F. 1987. - Aquatic macrophytes in Adirondack (New York) Lakes : patterns of species composition in relation to environment. Can. J. Bot., 66, 1449-1460.

James W.F., Barko J.W., Eakin H.L. \& Sorge P.W. 2002. - Phosphorus budget and management strategies for urban Wisconsin lake. Lake Reserv. Manage., 18, 149-163.

Kelly M.G. \& Whitton B.A. 1998. - Biological monitoring of eutrophication in rivers. Hydrobiologia, 348, 55-67.

Kelly M.G. 1998. - Use of community-based indices to monitor eutrophication in European rivers. Environ. Cons., 25, 22-29.

Klumpp A., Bauer K., Franz-Gerstein C. \& de Menezes M. 2002. Variation of nutrient and metal concentrations in aquatic macrophytes along the Rio Cachoeira in Bahia (Brazil). Environ. Intern., 28, 165-171.

Kohler A. \& Schneider S. 2003. - Macrophytes as bioindicators. Arch. Hydrobiol., Suppl., 147, 17-31.

Lafont M. 2001. - A conceptual approach to the biomonitoring of freshwater : the ecological ambient system. J. Limnol., 60, Suppl. $1,17-24$.

Lazaridou E., Orfanidis S., Haritonidis S \& Seferlis M. 1997. - Impact of eutrophication on species composition and diversity of macrophytes in the Gulf of Thessaloniki, Macedonia, Greece : First evaluation of the results of one year study. Fres. Envi. Bull., 6, 54-59.

Lehmann A. \& Lachavanne J.B. 1999. - Changes in the water quality of Lake Geneve indicated by submerged macrophytes. Freshwat. Biol., 42, 457-466.

Levin L.A., Boesch D.F., Covich A., Dahm C., Erseus C., Ewel K.C., Kneib R.T., Moldenke A., Palmer M.A., Snelgrove P., Strayer D. \& Weslawski J.M. 2001. The function of marine critical transition zones and the importance of sediment biodiversity. Ecosystems, 4, 430-451.

Ludovisi A., Pandolfi P. \& Taticchi M.I. 2004. - A proposed frameqork for the identification of habitat utilisation patterns of macrophytes in River Po catchment basin lakes (Italy). Hydrobiologia 523, 87-101. 
Mainstone C.P. \& Par W. 2002. - Phosphorus in rivers- ecology and management. Sci. Total Environ., 282, 25-47.

Martínez-Taberner A. \& Moyà G. 1993. - Submerged vascular plants and water chemistry in the coastal marsh Albufera de Mallorca (Balearic Islands). Hydrobiologia, 271, 129-139.

Nakai S., Inoue Y., Hosomi M. \& Murakami A. 1999. - Growth inhibition of blue-green algae by allelopathic effects of macrophyte. Water Sci. Tech., 39, 47-53.

Onaindia M., G. de Bikuña B. \& Benito I. 1996. - Aquatic plants in relation to environmental factors in Northern Spain. J. Environ. Manage., 46,123-137.

Palmer M.A., Bell S.L. \& Butterfiel I. 1992. A botanical classification of standing waters in Britain : applications for conservation and monitoring. Aquat. Conserv., 2, 125-143.

Papastergiadou E. \& Babalonas D. 1993. - The relationships between hydrochemical environmental factors and the aquatic macrophytic vegetation in stagnant and slow flowing waters. II. Evaluation of plant associations indicative value. Arch. Hydrobiol., 90, 475-491.

Peñuelas J. \& Sabater F. 1987. - Distribution of macrophytes in relation to environmental factors in the Ter River, N.E. Spain. Int. Revue Ges. Hydrobiol., 72,41-58.

Reid M.A. \& Quinn G.P. 2004. - Hydrologic regime and macrophyte assemblages in temporary floodplain wetlands: Implications for detecting responses to environmental water allocations. Wetlands, 24, 586-599.

Rodwell, J.S., Pigott C.D., Ratcliffe D.A., Malloch A.J.C., Birks H.J.B., Proctor M.C.F., Shimwell D.W., Huntley J.P., Radford E., Wigginton M.J. \& Wilkins P. 1995. - British plant communities. Volume 4 Aquatic communities, Swamps and Tall-herb Rens. Cambridge University Press, 283 pp.

Romero M.I. \& Onaindia M. 1995. - Fullgrown aquatic macrophytes as indicators of river water quality in the northwest Iberian Peninsula. Ann. Bot. Fenn., 32, 91-99.

Samecka-Cymerman A. \& Kempers A.J. 2002. Aquatic macrophytes as biomonitors of pollution by textile industry. Bull. Envi. Cont. Tox, 69, 82-96.

Sanchez-Carrillo S.M. \& Alvarez-Cobelas A. 2001. - Nutrient dynamics and eutrophication patterns in a semi-arid wetland : The effects of fluctuating hydrology. Wat. Air Soil Pollut., 131, 97-118.

Sanz de Galdeano J.M. \& Madariaga C. 1992. - Caracterización Hidrobiológica de la Red Fluvial de Alava y Gipuzkoa. Departamento de Economía, Planificación y Medio Ambiente. Gobierno Vasco,Vitoria, 511 p.

Schneider S. \& Melzer A. 2004. - Sediment and water nutrient characteristics in patches of submerged macrophytes in running waters. Hydrobiologia, 527, 195-207.

Schulz M., Kozerski H.P., Pluntke T. \& Rinke K. 2003. The influen- ce of macrophyte on sedimentation and nutrient retention in the lower River Spree (Germany). Water Res., 37, 569-578.

Seddon B. 1972. Aquatic macrophytes as limnological indicators. Freshwat. Biol., 2, 107-130.

Spencer D. \& Ksander G. 2003. Nutrient limitation of Zannichellia palustris and Elodea canadensis growing in sediments from Fall River, California. J. Freshwat. Ecol., 18, 207-213.

Spink A. \& Murphy J. 1997. - Distribution and environmental regulation of Batrachian Ranunculus in British rivers. Arch. Hydrobiol., $139:$ 509-525.

SPSS Inc. 1999. - Software 10.0 for Macintosh. Chicago, $400 \mathrm{p}$.

Swedish Environmental Protection Agency (EPA) 2002. Environmental Quality Criteria: Lakes and Watercourses. http://www.internat.naturvardsverket.se/documents/.

Szakowski M. \& Kolsowski S. 2001. - Habitat conditions of the phycocoenoses dominated by Luronium natans (L.) Rafin in Poland. Hydrobiologia, 455, 213-222.

Szoszkiewicz K., Karolewicz K., Lawniczak A. \& Dawson F.H. 2002. - An assessment of the MTR aquatic plant bioindication system for determining the trophic status of polish rivers. Pol. J. Environ. Stud., 11, 421-427.

Szymanowska A., Samecka-Cymerman A. \& Kempers A.J. 1999. Heavy metals in three lakes in West Poland. Ecot. Envi. Saf., 43, 21-29.

Thiébaut G. \& Muller S. 1999. - A macrophyte communities sequence as an indicator of eutrophication and acidification levels in weakly mineralised streams in north-eastern France. Hydrobiologia, 410, 17-24.

Thiébaut G \& Muller S. 2003. - Linking phosphorus pools of water, sediment and macrophytes in running waters. Ann. Limnol-Int. J. Lim., 39, 307-316.

Thiébaut G., Guérold F. \& Muller S. 2002. - Are trophic and diversity indices based on macrophyte communities pertinent tools to monitor water quality? Water Res., 36, 3602-3610.

Tusseau-Vuillemin M.H. 2001. - Do food processing industries contribute to the eutrophication of aquatic systems? Ecotoxicol. Environ. Saf., 50, 143-152.

Tutin T.G., Heiwood V.H., Burges N.A., Valentine D.H., Walters S.M. \& Webb D.A. 1964-1980. - Flora Europaea. 5 vol. Ed. Cambridge University Press, Cambridge, 2246 p.

Whitton B.A., Boulton P.N.G., Clegg E.M., Gemmell J.J., Graham G.G., Gustar R. \& Moorhouse T.P. 1998. - Long-term changes in macropytes of British rivers :1. River Wear. Sci. Total Environ., 210, 411-426.

Wilcock R.J. \& Nagels J.W. 2001. - Effects of aquatic macrophytes on physico-chemical conditions of three contrasting lowland streams : a consequence of diffuse pollution from agriculture? Water Sci. Tech., 43, 163-168. 